\title{
Government Support of Export Crediting: Implementation of the OECD Recommendations
}

\author{
M.V. Melnichuk \\ Financial University, \\ Center for International Finance, Financial Research Institute, Moscow, Russia \\ https://orcid.org/0000-0002-7720-7443
}

\begin{abstract}
Despite the ongoing sanction regimes, the Russian Federation is seeking to enhance the competitiveness of tradable goods and, hence, expand the international trade, increase exports and provide legal support for export crediting as a guarantee for maintaining the active trade balance of the country. Until now the regulatory framework for export crediting in the Russian Federation is not complete: certain provisions of the Russian and international law related to the area under study need harmonization. In this paper, the author examines the compliance of the terms of the OECD Arrangement on Officially Supported Export Credits with the regulatory framework governing export crediting in the Russian Federation. The paper analyzes the Russian legislation, strategic planning documents and in-house documents of organizations that form the national export support system. The analysis revealed the lack of legislative consolidation of export development in the Russian Federation, with regulatory issues reflected in non-core documents. The problem solution lies in improving the regulatory framework for support of export crediting so as to reduce the country risk and enhance the national competitiveness.
\end{abstract}

Keywords: export crediting; government (state) support; regulatory framework; public debt; corruption; country risk; income level

For citation: Melnichuk M.V. Government support of export crediting: implementation of the OECD recommendations. Upravlencheskie nauki = Management Sciences. 2018;8(4):17-24. DOI: 10.26794/2404-022X-2018-8-4-17-24

\section{Государственная поддержка экспортного кредитования: реализация рекомендаций ОЭСР}

\author{
М.В. Мельничук \\ Финансовый университет, \\ Центр международных финансов, Научно-исследовательский финансовый институт, Москва, Россия \\ https://orcid.org/0000-0002-7720-7443
}

\begin{abstract}
АННОТАЦИЯ
Несмотря на действующие санкционные режимы, Российская Федерация стремится к повышению уровня конкурентоспособности внешнеторговых товаров и, как следствие, увеличению международной торговли, наращиванию экспорта и правовому обеспечению экспортного кредитования, гарантирующему поддержание активного торгового баланса государства. До настоящего времени нормативное правовое регулирование экспортного кредитования в Российской Федерации не завершено: отдельные положения российского и международного права в исследуемой области нуждаются в гармонизации. В настоящей статье автор рассматривает соответствие условий Соглашения ОЭСР по официально поддерживаемым экспортным кредитам нормативному правовому полю в сфере экспортного кредитования в Российской Федерации. В работе анализируется законодательство Российской Федерации, документы стратегического планирования и локальные документы организаций,
\end{abstract}


формирующих национальную систему поддержки экспорта. В результате анализа устанавливается отсутствие законодательного закрепления развития экспорта в Российской Федерации и отражение вопросов регулирования в непрофильных документах. Решение проблемы лежит в плоскости совершенствования нормативного правового регулирования поддержки экспортного кредитования в целях снижения странового риска и повышения национальной конкурентоспособности.

Ключевые слова: экспортное кредитование; государственная поддержка; нормативное правовое регулирование; государственный долг; коррупция; страновой риск; уровень доходов

Для цитирования: Мельничук М.В. Государственная поддержка экспортного кредитования: реализация рекомендаций ОЭСР. Управленческие науки. 2018;8(4):17-24. DOI: 10.26794/2404-022X-2018-8-4-17-24

$\mathrm{O}$ $\mathrm{n}$ a long-term horizon, developing countries remain the growth driver of the world economy and international trade, with their economies progressing due to fundamental economic reasons - the increasing population and the growing income level tending to the Western countries average $^{1}$. Along with that, a significant part of international trade is implemented due to the active mechanism of export crediting that has gained widespread use abroad regardless of volatile income levels and certain country risks [1-3].

\section{Key Trends in the Export Credit Development in the Russian Federation}

For the first time, since 2013, the Russian Federation has gained positive growth rates in both general and non-raw non-energy exports. The consolidation of the national system of export support designated as a priority in the economic policy of the country had a favorable impact on the growth in all key sectors of the economy [4]. According to economic development forecasts until 2020 prepared by the Development Bank, export volumes will be increasing throughout this period (Fig. 1).

Along with the increase in exports, a positive trend has appeared in the export crediting, which, in addition to the favorable effects of the international trade expansion, is the second factor to have influenced the Russian public finances $[5,6]$.

Specifically, export credits in foreign currency extended with the government support constitute the external public debt. In the structure of the external debt of the Russian Federation, the money volume guarantees provided by the government rank the second after

\footnotetext{
${ }^{1}$ HSBC Global Connections Trade Forecast by Oxford Economics, 2015. URL: http://globaltrends.thedialogue.org/ publication/hsbc-global-connections-trade-forecast/ (accessed 06.08.2018).
}

the external bond debt and amount to US\$10,934.4 billion, or 21.29\%, as of August 2018 (Fig. 2).

When considering government guarantees in a dynamic context, it is easy to notice their stable volumes starting from 2013 (Fig. 3), both in absolute terms and in the structure of the external public debt.

In order to prevent the increase in the external public debt as well as for timely debt payment and export credit risk mitigation, exporting countries develop their own and implement international legal standards in national regulations governing the development and the state support of export credits.

To regulate export crediting that influences the public external debt levels, a number of documents are in force in the Russian Federation that generally comply with international legal standards and institutionalize export promotion in foreign countries.

\section{Arrangement on Officially Supported Export Credits: Content and Application Specifics for Differently Classified Countries}

As early as in the middle of the last century, the primacy in the export credit regulation having an impact on the global competition environment belonged to the Organization of European Economic Cooperation, now the OECD. Within the framework of the OECD, separate legal standards were adopted containing recommendations on the government support of export crediting that have gained international recognition. The key standards include: the 1978 Arrangement on Officially Supported Export Credits (the Arrangement); Recommendation on Bribery and Officially Supported Export Credit C(2006)163; Recommendation on Common Approaches to Officially Supported Export Credits and Environmental and Social Due Diligence C(2012)101; Recommendation on Common Approaches to the Environment and Officially Supported Export Credits C (2007) 65.

Implementation by exporting countries of the principles fixed in internationally recognized documents 


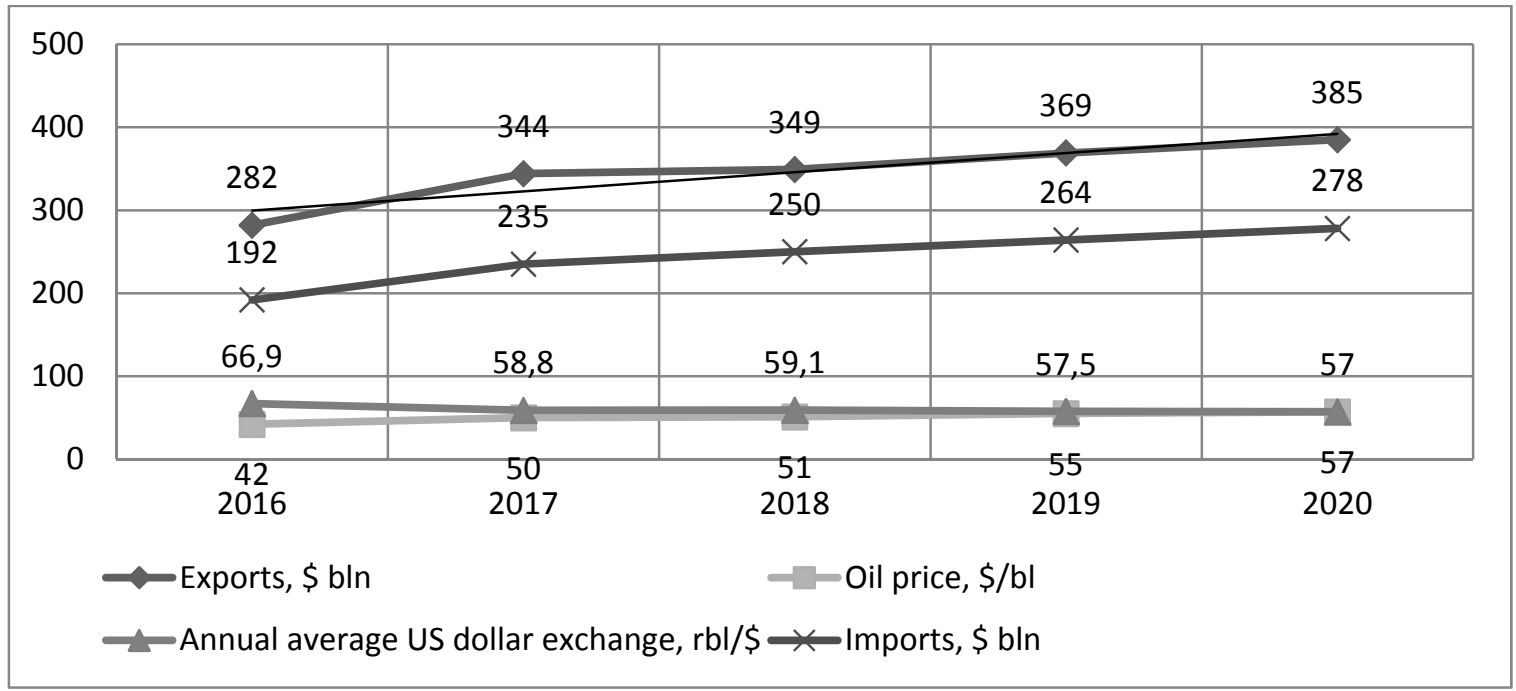

Fig. 1 / Puc. 1. Dynamics of macroeconomic indicators (an excerpt) / Динамика изменения макроэкономических показателей (выдержка)

Source / Источник: Forecast (2017) of Russia's economic development for 2018-2020. URL: https://new.veb.ru/files/?file=4219f36263352da3 31f3763197199c97.pdf / Прогноз (2017) экономического развития России на 2018-2020 гг. URL: https://new.veb.ru/files/?file=4219f36263 352da331f3763197199c97.pdf

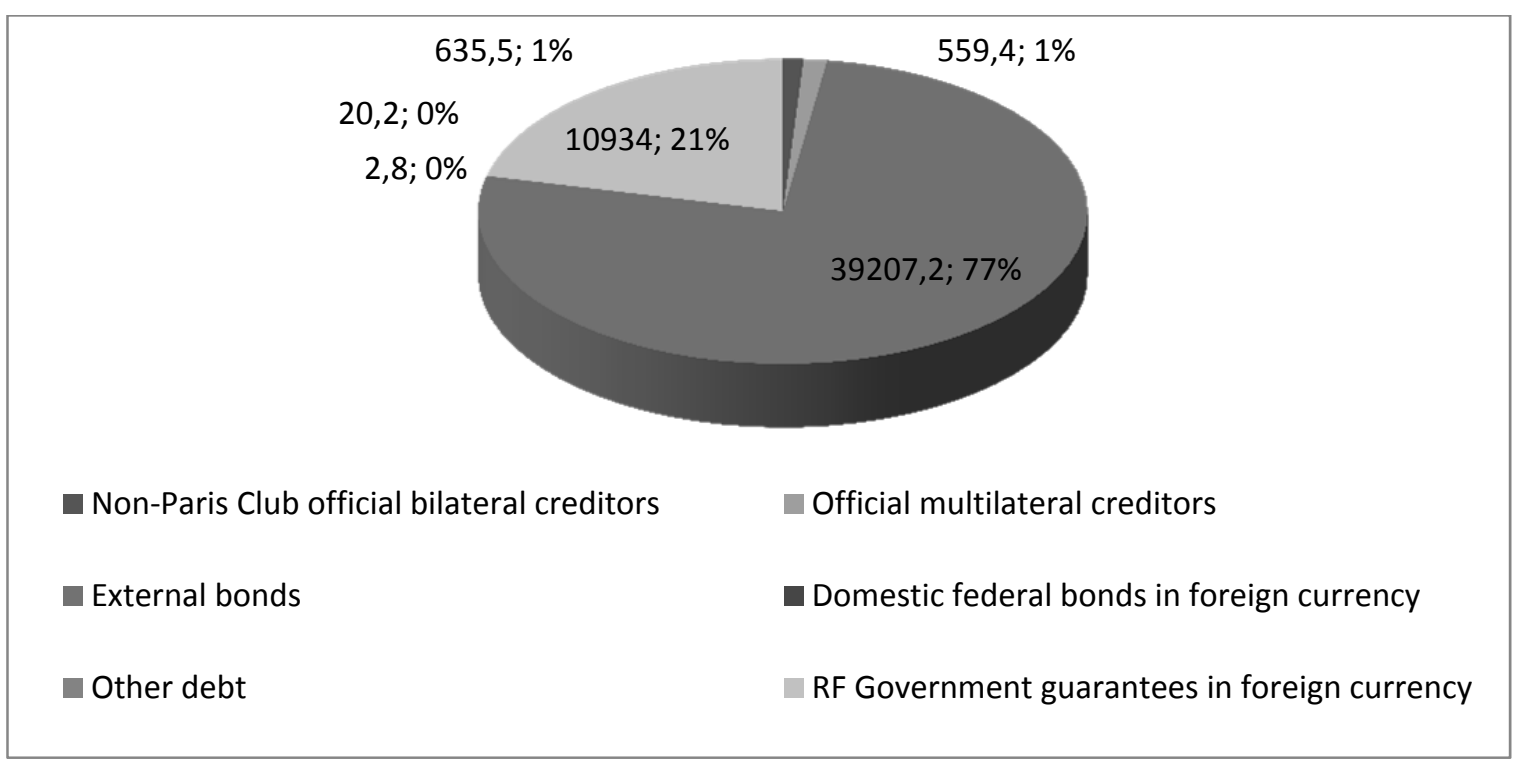

Fig. 2 / Puc. 2. The structure of the external public debt, US\$ billion, August 2018 / Структура государственного внешнего долга, млрд долл. США, август 2018 г.

Source / Источник: Public external debt of the Russian Federation (2011-2018), RF Ministry of Finance website URL: https://www.minfin.ru/ ru/perfomance/public_debt/external/structure / Государственный внешний долг Российской Федерации (2011-2018 гг.), Сайт Министерства финансов Российской Федерации, URL: https://www.minfin.ru/ru/perfomance/public_debt/external/structure/.

ensures guaranteed government support of export credits, provides the insurance cover, makes provision for extending money support in the form of subsidies, etc. In this regard, the compliance of the terms of international documents with the national legislation is an important area of research that will make it possible to identify gaps in the legal framework and outline benchmarks for further development of Russian exports.

The OECD Arrangement plays a special part in establishing the rules for the government support of 


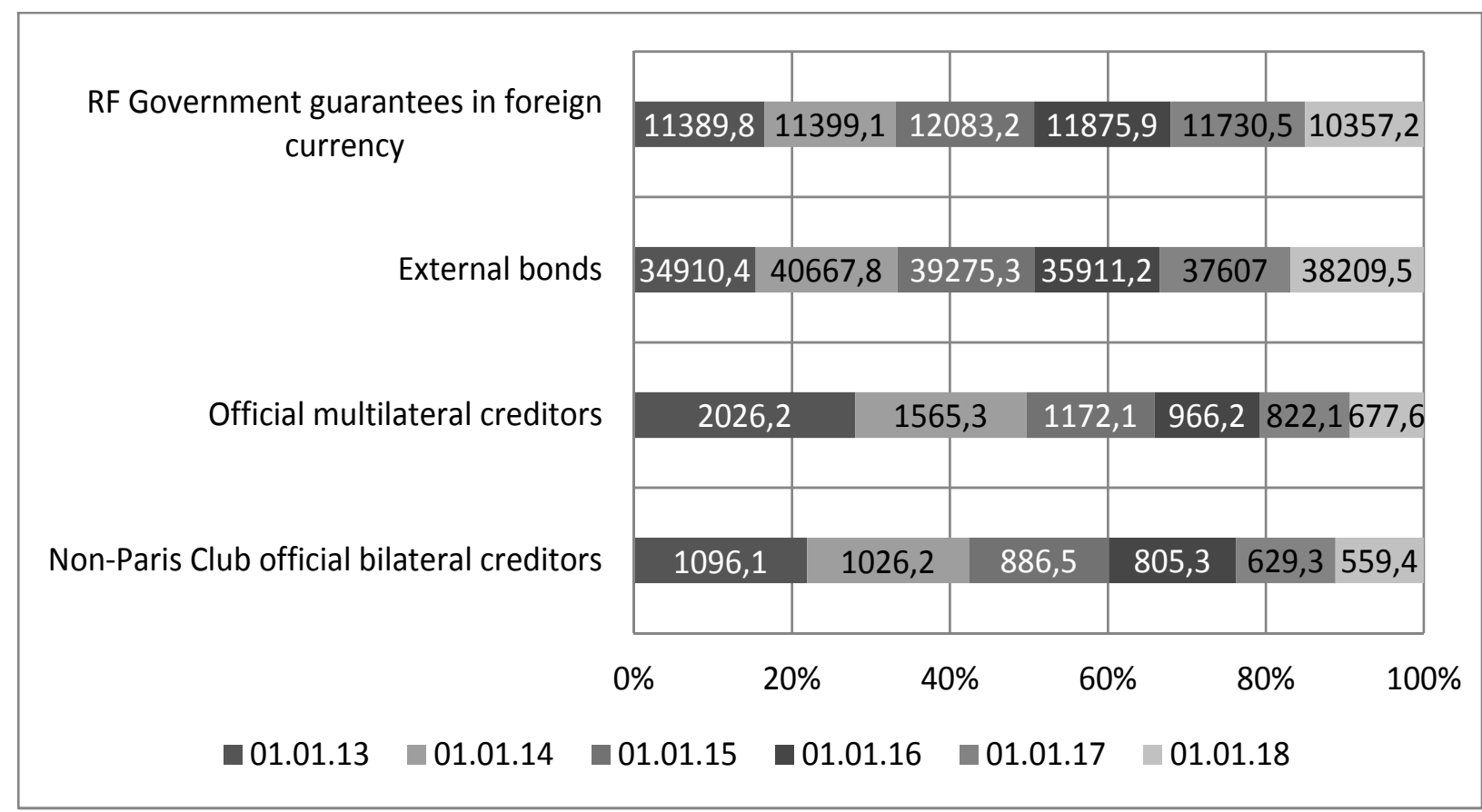

\section{Fig. 3 / Puc. 3. Dynamics of the key components of the Russian public external debt, US\$ billion / Динамика изменения ключевых составляющих государственного внешнего долга Российской Федерации, млрд долл. США}

Source / Источник: Compiled by the author on the basis of data presented on the website of the Ministry of Finance of the Russian Federation. URL: http://www.minfin.ru/ru/perfomance/public debt/external / составлен автором на основе данных, представленных на сайте Министерства финансов PФ. URL: http://www.minfin.ru/ru/perfomance/public_debt/external.

exports since the former determines the parameters for provision of financial support with government participation. The document defines the following types of support:

- export credit insurance, export credit guarantee;

- direct credit, financing and refinancing;

- interest rate support for export credits;

- any combination of the above.

The provisions of the Arrangement stipulate financial terms member states may put forward when extending officially supported export credits. The Arrangement applies to all types of the official export support provided by or on behalf of the state for the export of goods and (or) services, including financial leases that have a repayment term of two years or more. The document also applies to the tied aid, i.e. resources provided to developing countries on condition of acquisition of goods and services from a donor country.

The latest version of the OECD Arrangement (2018) classifies countries by categories, where Category I countries are high-income OECD states; all other countries are in Category II. This structuring is aimed at creating equal conditions for official export support in order to encourage competition among exporters based on the quality and prices of exported goods and services.

In general, the recommendations set out in the Arrangement adequately reflect the principal mechanisms for export credit support and contain requirements for:

- size and structure of down payments;

- repayment terms for export credits (max 8.5 for countries of Category I and max 10 years for Category II countries);

- conditions of the principal repayment and interest payment;

- interest rate and premium rate;

- country risk classification;

- sovereign risk assessment;

- quality of export credits coverage, etc.

Apart from the designated requirements, the document in question makes provision for assessment of country risks by the OECD experts. The Arrangement emphasizes that the applied risk classification is used solely for the purposes of the Arrangement rather than as an indicator of socio-economic development. Rus- 
Table 1 / Таблица 1

\begin{abstract}
Country Risk Classification of Participants to the Arrangement on Officially Supported
Export Credits (an excerpt) / Классификация страновых рисков участников Соглашения в отношении официально поддерживаемых экспортных кредитов (выдержка)
\end{abstract}

\begin{tabular}{|c|c|c|c|c|c|c|c|}
\hline No. & Country / Страна & $\begin{array}{c}01.01- \\
29.01\end{array}$ & $\begin{array}{c}22.01- \\
26.03\end{array}$ & $\begin{array}{c}19.03- \\
24.06\end{array}$ & $\begin{array}{c}17.06- \\
21.10\end{array}$ & $\begin{array}{c}14.10- \\
31.01\end{array}$ & $\begin{array}{c}24.01- \\
09.05\end{array}$ \\
\hline 1 & Afghanistan / Афганистан & 7 & 7 & 7 & 7 & 7 & - \\
\hline 2 & Albania / Албания & 7 & 7 & 7 & 7 & 7 & 7 \\
\hline 3 & Argentina / Аргентина & 5 & 5 & 5 & 5 & 5 & 5 \\
\hline 4 & Brazil / Бразилия & 5 & 6 & 6 & 6 & 6 & 6 \\
\hline 5 & Chad / Чад & 7 & 7 & 7 & 7 & 7 & 7 \\
\hline 6 & Chile / Чили & 2 & 2 & 2 & 2 & 2 & 2 \\
\hline 7 & Kuwait / Кувейт & 3 & 3 & 3 & 3 & 3 & 3 \\
\hline 8 & Honduras / Гондурас & 6 & 6 & 7 & 7 & 7 & 7 \\
\hline 9 & Mongolia / Монголия & 7 & 7 & 7 & 7 & 7 & 7 \\
\hline 10 & Russia / Россия & 7 & 7 & 7 & 7 & 7 & 7 \\
\hline
\end{tabular}

Source / Источник: Country Risk Classifications of the Participants to the Arrangement on Officially Supported Export Credits, 2018. URL: Country Risk Classifications of the Participants to the Arrangement on Officially Supported Export Credits, 2018. URL: http://www.oecd.org/ tad/xcred/cre-crc-historical-internet-english.pdf / Классификация страновых рисков участников Соглашения об официально поддерживаемых экспортных кредитах 2018 г. URL: http://www.oecd.org/tad/xcred/cre-crc-historical-internet-english.pdf.

sia, ranking the $7 \mathrm{th}^{2}$, belongs to the same country risk group as Afghanistan, Albania, Azerbaijan, Cameroon, Congo and others (Tab. 1). This fact indicates that the country has been designated as a low-income country, therefore, the applicable interest rates for credit risks corresponds to Category 7.

Such a low place in the country risk classification was characteristic of Russia only in 1999. Since 2000, it gradually rose to the level of " 4 " in 2015 . However, the economic and geopolitical transformations taking place in the country caused a sharp increase in country risks in the opinion of the Participants to the OECD Arrangement.

${ }^{2}$ Country Risk Classifications of the Participants to the Arrangement on Officially Supported Export Credits, 2018. URL: http://www.oecd.org/tad/xcred/cre-crc-historicalinternet-english.pdf (accessed 08.09.2018).

\section{Consistency between the Russian Regulatory Framework and the OECD Arrangement}

The relatively recent tradition of rule-making in relation to export crediting in the Russian Federation made it possible to develop a mechanism for extending credits and guarantees within the framework of the Concept for the Development of the State Financial (Guarantee) Support for Exporting Industrial Products, RF Government Order No. $1493-\mathrm{p}^{3}$. In general, the provisions of the Concept are consistent with the principles set out in the OECD Arrangement as shown in Tab. 2 .

${ }^{3}$ The concept of public financial (guarantee) support for
exports of industrial products. The government of the Russian
Federation Order dated October 14, 2003. URL: http://docs. cntd.ru/document/901877013 (accessed 18.09.2018). (In Russ.). 
Table 2 / Таблица 2

\section{Matching the OECD Arrangement on Officially Supported Export Credits to the Regulatory Framework of the Russian Federation / Сопоставление Соглашения ОЭСР по официально поддерживаемым экспортным кредитам и НПА Российской Федерации}

\begin{tabular}{|c|c|c|}
\hline & OECD / ОЭСР* & Russian Federation / Российская Федерация** \\
\hline 1 & $\begin{array}{l}\text { Classification of countries by credit repayment } \\
\text { terms / Классификация стран по условиям } \\
\text { погашения кредитов }\end{array}$ & $\begin{array}{l}\text { Risk categories of the borrowing country / Категории риска } \\
\text { государства-заемщика } \\
\text { Guarantee coverage according to the risk category / Величина } \\
\text { гарантийного покрытия в соответствии с категорией риска }\end{array}$ \\
\hline 2 & $\begin{array}{l}\text { Terms of crediting depending on the } \\
\text { country category ( } 4.5 \text { to } 10 \text { years) / Сроки } \\
\text { кредитования в зависимости от категории } \\
\text { страны (от } 4,5 \text { до } 10 \text { лет) }\end{array}$ & $\begin{array}{l}\text { Terms of crediting depending on groups of exported goods ( } 3.5 \\
\text { to } 10 \text { years) / Сроки кредитования в зависимости от групп } \\
\text { экспортируемых товаров (от } 3,5 \text { до } 10 \text { лет) }\end{array}$ \\
\hline 3 & $\begin{array}{l}\text { Refinancing or interest rate support / } \\
\text { Рефинансирование или поддержка } \\
\text { процентной ставки }\end{array}$ & $\begin{array}{l}\text { Conditions of partial reimbursement of interest rates / Условия } \\
\text { возмещения части процентных ставок }\end{array}$ \\
\hline
\end{tabular}

* Trade and Agriculture Directorate Particupants to the Arrangement on Officially Supported Export credits, 2018. URL: http://www.oecd.org/ officialdocuments/publicdisplaydocumentpdf/?doclanguage=en \&cote=tad/pg(2018)1 (accessed 10.08.2018).

** The concept of public financial (guarantee) support for exports of industrial products. The government of the Russian Federation Order dated October 14, 2003. URL: http://docs.cntd.ru/document/901877013 (accessed 16.10.2018). (In Russ.).

However, as follows from the above-mentioned Concept, the rules of the Arrangement for the Russian Federation apply only to the export of industrial products. In turn, the Arrangement emphasizes that it does not cover agricultural products and military products.

It is to be admitted that the lack of a unified law for exports regulation in Russia complicates the development of specific goals and implementation of government support of export credits that is based solely on strategic planning documents. Among them are the State Program for the Development of Foreign Economic Activity, the Innovative Development Strategy, the Concept of Exports Financing, etc.

Another significant fact is the compliance of the principles set out in the Arrangement with the Russian legal framework in the area of combating bribery of foreign public officials. The analysis shows that in Russia these provisions are implemented without approved local regulations. Neither the strategic planning documents nor the national legislation set out special requirements for mandatory examination to detect acts of bribery in relation to participants of export projects implemented with financial support from the state. All participants of such projects are guided by the general rules laid down in Federal Law No. 273-FZ "On Combating Corruption" 4

Moreover, in Russia there are no legislatively stated requirements for the mandatory assessment of environmental and social aspects of export projects carried out with the government support in the form of export credits. However, these requirements are partially met by Vnesheconombank in implementing measures of providing financial support of exports.

Furthermore, Russia does not have a single limit on the maximum government support level based on the export contract value; there are no established restrictions relating to the conditions for granting export credits; nor are there down payment requirements and the minimum permitted credit rate. The budget legislation of the Russian Federation does not contain rules stipulating assumption of long-

${ }^{4}$ Federal Law “On Combating Corruption" dated December 25, 2008. URL: http://www.consultant.ru/document/cons_doc_ LAW_82959/ (accessed 06.08.2018). (In Russ.). 
term financial liabilities within the framework of concessional export credit mechanisms.

\section{Application of Export Credit Requirements by Russian Organizations}

In the Export Development Strategy, the creation of conditions for large-scale credit and insurance activities is designated as one of the most important areas of export development in the Russian Federation.

In 2013, a mechanism for providing subsidies in the form of property contribution to Vnesheconombank aimed at recovering high-tech product manufacturing costs was launched in Russia. In general, the national export support system in the Russian Federation has been established. The exceptions are agencies for export promotion and foreign direct investment operating in Western countries that have no counterparts in Russia.

At the level of local regulations, the majority of organizations that form the national export system are guided by the international OECD standards. In particular, the Rules for Comprehensive Insurance of Export Credits approved by a resolution of the Directors' Board of EXIAR PJSC consolidate the insurer's obligation to ensure compliance with legislation, including the legislation on environmental protection; the General Guidelines on Export Financing and Export Credit Insurance necessitate compliance with the OECD Arrangement.

The Anti-Bribery requirements of the Arrangement in the context of providing export credits are taken into account by Vnesheconombank as part of the "General Guidelines on Export Financing and Export Credit Insurance" ${ }^{5}$. According to the document, ESCAR carries out an extended assessment of exporters in the part of their being "blacklisted",

${ }^{5}$ General Guide to Export Finance and Export Credit Insurance, 2013. URL: http://www.veb.ru/common/upload/files/veb/br/ export/exfin_proc_r.pdf (accessed 16.10.2018). (In Russ.). prosecuted and brought charges against in court, the presence of bribery, etc.

The same document defines the procedure for assessment of the environmental impact and social effect of export projects to ensure their harmonization with the OECD requirements, and classifies transactions by categories A (negative environmental impact), B (less adverse environmental impact), $C$ (potential environmental impact is minimal or absent).

Therefore, non-statutory regulations governing Russian organizations that form the national export support system partially fill the gaps in the legal framework for export crediting in the Russian Federation.

\section{Conclusion}

Summarizing the results of the performed analysis, the following conclusions are drawn:

1. Separate strategic planning documents (Concept of the State Financial Support for Exporting Industrial Products) contain elements of the OECD Recommendations, and the Export Development Strategy until 2030 provides for implementation of the OECD Officially Supported Export Credit Arrangement. However, a clear consistency between the OECD Arrangement and the strategic planning documents of the Russian Federation is not traced. Basically, the implementation of the OECD Arrangement is governed by the Russian non-core legislation, and in some cases by local documents of individual organizations.

2. Regulation of the rules and procedures for the provision of export support is largely implemented at the level of non-statutory regulation; in particular, through adoption of relevant documents by Vnesheconombank and EXIAR PJSC of which the General Guidelines for Export Financing and Export Credit Insurance is the key document for regulating export support measures.

\section{REFERENCES}

1. Begchin N.A., Bogacheva O.V., Smorodinov O.V. Expenditure reviews as a tool for managing public finances in OECD countries: A theoretical aspect. Nauchno-issledovatel'skii finansovyi institut. Finansovyi zhurnal = Financial Research Institute. Financial Journal. 2018;(3):49-63. (In Russ.). DOI: 10.31107/2075-1990-2018-3-49-63

2. Ogryzov A. A. US experience in supporting export and export credit. Ekonomicheskie nauki = Economic Sciences. 2015;(132):121-125. (In Russ.).

3. Ponamorenko V.E., Shulyatyev I.A. Prospects for the formation of the legal framework of export crediting in the Eurasian Economic Union. Tamozhennoe delo = Customs Affairs. 2016;(4):16-20. (In Russ.). 
4. Spartak A.N., Knobel A. Yu., Flegontova T.A. et al. Prospects for increasing Russian non-oil exports. Moscow: All-Russian Academy of Foreign Trade; 2018. 132 p. URL: https://www.csr.ru/wp-content/uploads/2018/04/Report-Non-energy-Export.pdf (In Russ.).

5. Mokhnatkina L.B. Balanced budget and public debt as indicators of financial and budgetary security of the region. Nauchno-issledovatel'skii finansovyi institut. Finansovyi zhurnal = Financial Research Institute. Financial Journal. 2018;(2):106-119. (In Russ.). DOI: 10.31107/2075-1990-2018-2-106-119

6. Puzankov K.M. Mechanism of supporting export credits in Russian rubles on the basis of OECD practice. Mezhdunarodnaya torgovlya i torgovaya politika = International Trade and Trade Policy. 2015;(3):45-51. (In Russ.).

\section{СПИСОК ИСТОчНИКОВ}

1. Бегчин Н.А., Богачева О.В., Смородинов О.В. Обзоры расходов как инструмент управления общественными финансами в странах ОЭСР: теоретический аспект. Научно-исследовательский финансовый институт. Финансовый журнал. 2018;(3):49-63. DOI: 10.31107/2075-1990-2018-349-63

2. Огрызов А.А. Опыт США по поддержке экспорта и экспортному кредитованию. Экономические науки. 2015;(132):121-125.

3. Понаморенко В.Е., Шулятьев И.А. Перспективы формирования правовых основ экспортного кредитования в Евразийском экономическом союзе. Таможенное дело. 2016;(4):16-20.

4. Спартак А.Н., Кнобель А. Ю., Флегонтова Т.А. и др. Перспективы наращивания российского несырьевого экспорта. М.: Всероссийская академия внешней торговли; 2018. 132 c. URL: https://www.csr.ru/wp-content/uploads/2018/04/Report-Non-energy-Export.pdf

5. Мохнаткина Л.Б. Сбалансированность бюджета и государственный долг как индикаторы финансово-бюджетной безопасности региона. Научно-исследовательский финансовый институт. Финансовый журнал. 2018;(2):106-119. DOI: 10.31107/2075-1990-2018-2-106-119

6. Пузанков К.М. Механизм поддержки экспортного кредитования в рублях на базе практики ОЭСР. Международная торговля и торговая политика. 2015;(3):45-51.

\section{ABOUT THE AUTHOR}

Marina V. Melnichuk - Dr. Sci. (Econ.), Full Professor, Financial University, Chief Researcher at the Center for International Finance, Financial Research Institute, Moscow, Russia

mvmelnichuk@fa.ru

\section{ИНФОРМАЦИЯ ОБ АВТОРЕ}

Марина Владимировна Мельничук - доктор экономических наук, профессор, Финансовый университет, главный научный сотрудник Центра международных финансов, Научно-исследовательский финансовый институт, Москва, Россия

mvmelnichuk@)fa.ru 